\title{
Relative biomass and size class of ant prey Cataglyphis bicolor (Fabricius, 1793) (Hymenoptera Formicidae) in the Reghaiia wetland reserve (Algeria)
}

\author{
Ouarab Samial* \& Doumandji Salaheddine $^{2}$ \\ ${ }^{1}$ Department of Biology and Cellular Physiology, University of Saad Dahlab, Blida 1, Animal Ecobiology \\ Laboratory, 09000 Blida, Algeria \\ ${ }^{2}$ Department of Zoology, National Agronomic School, El Harrach, 16200 Algiers, Algeria \\ ${ }^{*}$ Corresponding author, e-mail: souarab2002@yahoo.fr
}

ABSTRACT

KEY WORDS
This work focuses on the study of the diet of the ant Cataglyphis bicolor (Fabricius, 1793) (Hymenoptera Formicidae) in the natural reserve of the Reghaïa wetland through the analysis of two nests. This study shows that Hymenoptera dominates in the trophic menu of this species at $92.7 \%$ for Nest 1 and $87 \%$ for Nest 2, with a total of 60 species divided between 3 classes, 10 orders and 31 families. The most consumed species by C. bicolor is Messor barbarus (Linnaeus, 1767) (Hymenoptera Formicidae) with $87 \%$ (Nest 1) and $82.2 \%$ (Nest 2). In terms of biomass, a species of Coleoptera dominates either Ophonus sp. $($ B. $\%=9.36 \%)$. Messor barbarus dominates in relative abundance and has only a very small part of the biomass ingested $(0.37 \%)$. The size of C. bicolor prey species is between 1 and $24 \mathrm{~mm}$ for Nest 1 and 1 and 30 $\mathrm{mm}$ for Nest 2.

Diet; Relative biomass; Size class; Cataglyphis bicolor; Reghaïa wetland reserve; Algeria.

\section{INTRODUCTION}

Cataglyphis bicolor (Fabricius, 1793) (Hymenoptera Formicidae) is an ant predator of strictly diurnal activity (Cagniant, 1973). Its diet consists mainly of dead insects, often other Formicidae: Messor Forel, 1890 and Camponotus Mayr, 1861, but also adults of other Cataglyphis Förster, 1850. Moreover, it feeds on various live prey, like caterpillars and other larvae, adult beetles, small arachnids, and sweet vegetable liquids (Cagniant, 2009).

According to Cagniant (2009), Cataglyphis are found in North Africa from the seashore to $2800 \mathrm{~m}$ at Hoggar. These ants nest in open places, large clearings, mountain pastures, steppes, wastelands, and unpaved streets. They appear to be anthro- pogenic and their expansion has been favored by human activities. Colonies are established in flat areas, avoiding steep slopes or rock scree. In C. bicolor, the large-sized workers go out to supply, while the small ones usually stay at the nest to care for the brood (Cagniant, 2009).

Several authors have studied the ecology and behavior of this ant: Bernard (1948), Grassé (1951), Délye (1957), Bernard (1968), Cagniant (1973), Délye (1974), Hölldobler \& Wilson (1993), Heusser \& Wehner (2002), and Dietrich \& Wehner (2003).

In Algeria, Molinari (1989), Baouane (2002), and Ouarab et al. $(2006,2010)$ examined the feeding of this ant in the Reghaïa wetland. Elsewhere, other authors have examined the trophic menu of C. bicolor, notably Sekour (2002) in Mergueb, 
Talmat (2002) in the region of Tigzirt and Iflissen, Ziada (2006) and Ziada \& Doumandji (2008) in the region of Guelma, and Moulai et al. (2006a, b) in the region of Bejaia. Cataglyphis bicolor itself plays the role of prey.

The aim of this work is to study trophic behavior and to address the quantitative aspect of $C$. bicolor in relation to the size and weight of the prey present in its diet.

\section{MATERIAL AND METHODS}

The Reghaïa wetland has been a Ramsar site since $2003\left(36^{\circ} 46^{\prime}\right.$ to $36^{\circ} 47^{\prime} \mathrm{N}, 3^{\circ} 19^{\prime}$ to $3^{\circ} 20^{\prime} \mathrm{E}$, Fig. 1) and a nature reserve since 2016. It is located in the eastern part of the Mitidja plain, on the edge of the Mediterranean Sea. It is bounded on the north by the Mediterranean Sea, on the west by Oued El Hamiz, on the south by the eastern part of Mitidja and on the east by Oued Boudouaou and by the first hills that announce the Kabyle massif (Mutin, 1977).

As the climate of the study area is tempered by the proximity of the Mediterranean Sea, its climate belongs to the subhumid bioclimatic stage in warm winter. Rainfall fluctuates from year to year between 200 and $800 \mathrm{~mm}$, and reached $760.6 \mathrm{~mm}$ in 2004. The average annual temperature is $18.0^{\circ} \mathrm{C}$.

Arthropod body fragments were collected around the entrance to the nest of $C$. bicolor. They were put in paper bags bearing information on the date and place of harvest. Sampling was carried out during the months of July and September 2003.

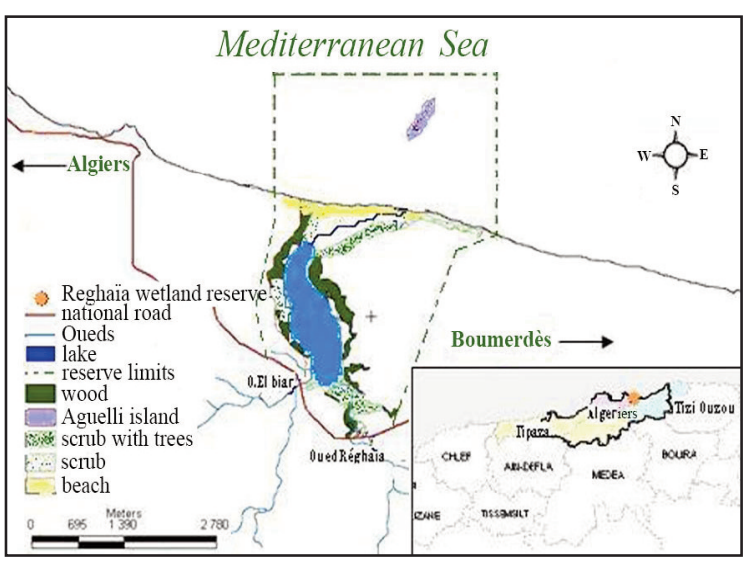

Study area: Reghaïa wetland reserve (Algeria).
Sometimes, the operator could not collect all the remains of the fragments and was forced to dig at the entrance of the nest to recover soil containing the sclerotinized fragments.

In the trophic regime of the ant $C$. bicolor, the recognition of arthropods was carried out in the entomology laboratory of the El Harrach, National Agronomic School. The systematic analysis of the insects was carried out in a progressive way. The determination was made by observations with a binocular loupe whose magnification is 10x1.6. Taxonomic research was carried, usually, up to the family or genus and rarely up to the species for insects, and only up to order or class for other arthropods. Among the Arthropods, the Aranea are recognizable by their jaw legs, cephalothorax, very hairy legs and their eyes. Crustacea Isopoda and Diplopoda are sometimes difficult to discern. Formicidae are identifiable by their head and thorax.

From a fragment, the estimate of the size of each species (E.T.P.) was carried out as follows. The length of the sclerotinized part is measured using a small $2 \times 10 \mathrm{~mm}$ graph paper tab. Knowing the proportions of the Arthropoda bodies, the size of the sample is estimated from the fragment present. There is a certain margin of error that can be reduced by comparison with the species of the insectarium of the National Agricultural School of El Harrach. For Orthoptera and Heteroptera, the head is $1 / 6$ th of the whole body, $1 / 2$ for the abdomen and $1 / 3$ for the thorax. These measures can be variable, especially when it comes to polymorphic species such as the ants Messor barbarus, Camponotus sp. and Pheidole pallidula.

The results were analyzed using different ecological indices of composition, such as total wealth, or the number of species present in all C. bicolor nests (Blondel, 1969). The relative abundance corresponds to the percentage of individuals of a species taken into consideration in relation to the total of all species combined (Dajoz, 1971; Bigot \& Bodot, 1973); percentage of biomass corresponds to the percentage of the weight of individuals of a species $(\mathrm{Pi})$ relative to the total weight of the whole prey (P) (Vivien, 1973).

\section{RESULTS}

Relative to the contents of two nests, the trophic 
diet of C. bicolor includes 60 prey species (Table 1). These species are divided into 3 classes, 10 orders and 31 families. There were 439 prey for the first nest and 399 prey species for the second nest. These are part of 10 orders of which one of them is well represented (Hymenoptera with $92.7 \%$ in Nest 1 and $87 \%$ in Nest 2). Messor barbarus is present with $87 \%$ in Nest 1 and $82.2 \%$ in Nest 2.

In the trophic diet of $C$. bicolor, the highest relative biomass value is for Ophonus sp. (B.\% = 9.36\%) (Table 1), but, in terms of relative abundance, this species is poorly noted in the diet of $C$. bicolor. Then comes that of an undetermined species of Oniscidae that has 31 individuals (B.\% $=9.36 \%$ ) and Aiolopus strepens (Latreille, 1804) in third place $($ B. $\%=8.61 \%)$. Other species participate with low rates.

The size classes of the species found in the diet of $C$. bicolor in the Reghaïa wetland range between 1 and $24 \mathrm{~mm}$ for Nest 1 and 1 and $30 \mathrm{~mm}$ for Nest 2 (Fig. 2). The most abundant size classes are $5 \mathrm{~mm}$ $(\mathrm{AR} \%=20 \%), 6 \mathrm{~mm}(\mathrm{AR} \%=8.9 \%)$, and $8 \mathrm{~mm}$ $(\mathrm{AR} \%=13.3 \%)$ for Nest 1 . Class of $5 \mathrm{~mm}$ is represented by Sinoxylon sp. and Ophthalmicus sp., and that of $8 \mathrm{~mm}$ by Crypticus obesus and Larinus sp. 2. For Nest 2, the most represented size classes are $4 \mathrm{~mm}(\mathrm{AR} \%=10.8 \%), 5 \mathrm{~mm}(\mathrm{AR} \%=10.8 \%)$, $6 \mathrm{~mm}(\mathrm{AR} \%=10.8 \%)$, and $8 \mathrm{~mm}(\mathrm{AR} \%=$ $18.9 \%$ ). The size class of $8 \mathrm{~mm}$ corresponds to Cassida ferruginea, Carpocoris sp., and Otiorrhynchus sp. (Fig. 3).

\section{DISCUSSION}

The study of the diet of the ants C. bicolor in the Reghaïa wetland shows that the most abundant prey species found in the nests of C. bicolor are Formicidae (Hymenoptera), particularly Messor barbarus (first nest AR. $\%=87.0 \%$, second nest AR\% $\%=82.2 \%$ ). Bernard (1951) wrote that $C$. bicolor hunts alone or in small groups and attacks preferably ants of the genus Messor. The present results are consistent with those found by Bernard (1951) and Ouarab et al. (2006), which indicate that Formicidae dominate in the C. bicolor diet. These authors mention Tapinoma nigerrimum with $33.4 \%$ for Nest 1 and $68.8 \%$ for Nest 2 around Reghaïa marsh. Messor barbarus (19\%) is dominant near Tigzirt and the Mergueb reserve
(46.3\% in Nest 1 and $62.5 \%$ in Nest 2). In the last station cited, Sekour et al. (2007) report that Formicidae are first with Messor barbarus (56.2\%). Similarly, the high frequency of Messor barbarus in C. bicolor diet is already mentioned by Moulai et al. (2006a) near Bejaia (49.8\% in a wasteland and $34.3 \%$ in a scrubland). Filali \& Doumandji (2008) note the contribution of the harvesting ant in the diet of $C$. bicolor with a rate of $37.4 \%$. Djennoune et al. (2018) in two localities of Kabylie in Algeria presented the biochemical composition of Messor sp. The results found show that this species is very rich in proteins $(72.74 \%)$, low in lipids $(5.05 \%)$ and no carbs. According to these same authors (Filali \& Doumandj, 2008), the total energy value of these three biochemical components in Messor sp. equals $336.41 \mathrm{kcal} / \%$ dry matter.

In the trophic diet of C. bicolor, the highest relative biomass value is noted for Ophonus sp. (B.\% $=9.36 \%$ ). Ziada (2006) reports that C. bicolor itself as prey has the highest biomass rate (B. $\%=$ $12.4 \%)$. In our experience, the same C. bicolor is totally absent from $C$. bicolor's menu near the Marsh of Reghaïa. In Guayaza, Guerzou (2009) reports that an indeterminate species of lizard (Lacertidae sp. ind.) is dominant with $32.5 \%$. The following authors, who treated the diet of C. bicolor, did not exploit their results by relative biomass (Barech, 1999; Sekour, 2002; Ouarab et al., 2006, 2010; Moulai et al., 2006a, 2006b; Filali \& Doumandji, 2008). Ziada (2006) and Guerzou (2009), on the contrary, were interested in this aspect.

The size classes of the species found in the diet of $C$. bicolor in the Reghaïa wetland range from 1 to $24 \mathrm{~mm}$ for Nest 1 and from 1 to $30 \mathrm{~mm}$ for Nest 2. Filali \& Doumandji (2008) near Azzaba find values that vary between 1 and $45 \mathrm{~mm}$. Moulai et al. (2006a) report larger sizes of prey of C. bicolor at a fallow land near Bejaia ranging from 3 to $73 \mathrm{~mm}$, in a garrigue of the same sizes comparable to those found in this study. Also Ziada (2006) finds very large sizes between 1 and $100 \mathrm{~mm}$. In the vicinity of Reghaïa marsh, the most common size class is $5 \mathrm{~mm}$ (A.R.\% $\% 20 \%$ ) for Nest 1 and $8 \mathrm{~mm}$ for Nest 2 (A.R.\% = 18.9\%). Ziada (2006), near Guelma, mentions that the most ingested prey (27\%) by C. bicolor are those of sizes between 4.5 and $5.4 \mathrm{~mm}$. Filali \& Doumandji (2008) in Azzaba 


\begin{tabular}{|c|c|c|c|c|c|c|c|}
\hline \multirow[b]{2}{*}{ Ordres } & \multirow[b]{2}{*}{ Families } & \multirow[b]{2}{*}{ Species } & \multicolumn{2}{|c|}{ Nest 1} & \multicolumn{2}{|c|}{ Nest 2} & \multirow{2}{*}{ В \% } \\
\hline & & & ni. & AR\% & ni. & AR\% & \\
\hline Aranea & -------- & Aranea sp. 1 & 0 & 0 & 1 & 0.25 & 0.94 \\
\hline Ricinuleida & -------- & Ricinuleida sp. 1 & 0 & 0 & 1 & 0.25 & 0.94 \\
\hline Isopoda & -------- & Isopoda sp. 1 & 0 & 0 & 31 & 7.77 & 9.36 \\
\hline \multirow{4}{*}{ Orthoptera } & \multirow{3}{*}{ Acrididae } & Aiolopus strepens & 0 & 0 & 1 & 0.25 & 8.61 \\
\hline & & Pezotettix giornai & 0 & 0 & 1 & 0.25 & 2.62 \\
\hline & & Acrididae sp. 1 & 1 & 0.23 & 0 & 0 & 7.49 \\
\hline & Gryllidae & Gryllidae sp. 1 & 1 & 0.23 & 0 & 0 & 5.62 \\
\hline Dermaptera & Dermaptera & Dermaptera sp. 1 & 0 & 0 & 1 & 0.25 & 5.62 \\
\hline \multirow{8}{*}{ Heteroptera } & Scutelleridae & Ancyrosoma albolineata & 0 & 0 & 1 & 0.25 & 0.37 \\
\hline & Reduviidae & Reduviidae sp. 1 & 1 & 0.23 & 0 & 0 & 0.94 \\
\hline & \multirow{3}{*}{ Pentatomidae } & Carpocoris sp. & 1 & 0.23 & 0 & 0 & 1.69 \\
\hline & & Sehirus sp. & 0 & 0 & 1 & 0.25 & 0.56 \\
\hline & & Sciocoris sp. & 0 & 0 & 1 & 0.25 & 0.28 \\
\hline & \multirow{3}{*}{ Lygaeidae } & Ophthalmicus sp. & 1 & 0.23 & 0 & 0 & 0.56 \\
\hline & & Lygaeidae sp. 1 & 0 & 0 & 1 & 0.25 & 0.56 \\
\hline & & Lygaeidae sp. 2 & 0 & 0 & 1 & 0.25 & 0.37 \\
\hline \multirow{3}{*}{ Homoptera } & \multirow{2}{*}{ Jassidae } & Jassidae sp. 1 & 1 & 0.23 & 0 & 0 & 0.19 \\
\hline & & Jassidae sp. 2 & 1 & 0.23 & 0 & 0 & 0.19 \\
\hline & Fulgoridae & Fulgoridae sp. 1 & 1 & 0.23 & 0 & 0 & 0.37 \\
\hline \multirow{22}{*}{ Coleoptera } & Coleoptera & Coleoptera sp. 1 & 0 & 0 & 1 & 0.25 & 5.62 \\
\hline & \multirow{3}{*}{ Harpalidae } & Harpalus fulvus & 0 & 0 & 1 & 0.25 & 7.49 \\
\hline & & Carterus sp. & 0 & 0 & 2 & 0.5 & 5.62 \\
\hline & & Ophonus sp. & 0 & 0 & 2 & 0.5 & 9.36 \\
\hline & Elateridae & Elateridae sp. 1 & 0 & 0 & 1 & 0.25 & 0.94 \\
\hline & \multirow{3}{*}{ Tenebrionidae } & Crypticus obesus & 2 & 0.46 & 1 & 0.25 & 1.31 \\
\hline & & Tenebrionidae sp. 1 & 1 & 0.23 & 0 & 0 & 1.87 \\
\hline & & Pachychila sp. & 0 & 0 & 1 & 0.25 & 1.87 \\
\hline & Bostrychidae & Bostrychidae sp. 1 & 1 & 0.23 & 0 & 0 & 1.12 \\
\hline & \multirow[t]{2}{*}{ Chrysomelidae } & Cassida ferruginea & 1 & 0.23 & 0 & 0 & 0.37 \\
\hline & & Chrysomelidae sp. 1 & 1 & 0.23 & 0 & 0 & 0.09 \\
\hline & \multirow{3}{*}{ Bruchidae } & Bruchidius sp. & 1 & 0.23 & 0 & 0 & 0.19 \\
\hline & & Bruchidae sp. 1 & 1 & 0.23 & 0 & 0 & 0.19 \\
\hline & & Sinoxylon sp. & 1 & 0.23 & 0 & 0 & 0.75 \\
\hline & \multirow{8}{*}{ Curculionidae } & Larinus sp. 1 & 1 & 0.23 & 1 & 0.25 & 1.69 \\
\hline & & Larinus sp. 2 & 1 & 0.23 & 0 & 0 & 1.50 \\
\hline & & Otiorhynchus sp. & 3 & 0.68 & 0 & 0 & 1.69 \\
\hline & & Curculionidae sp. 1 & 1 & 0.23 & 0 & 0 & 0.09 \\
\hline & & Curculionidae sp. 2 & 1 & 0.23 & 0 & 0 & 0.09 \\
\hline & & Curculionidae sp. 3 & 1 & 0.23 & 1 & 0.25 & 0.02 \\
\hline & & Sitona sp. & 2 & 0.46 & 0 & 0 & 1.31 \\
\hline & & Nanophvies sp. & 1 & 0.23 & 0 & 0 & 0.13 \\
\hline
\end{tabular}

Table 1/1. Relative abundances of prey species inventoried at the entrance to the nest of Cataglyphis bicolor. 


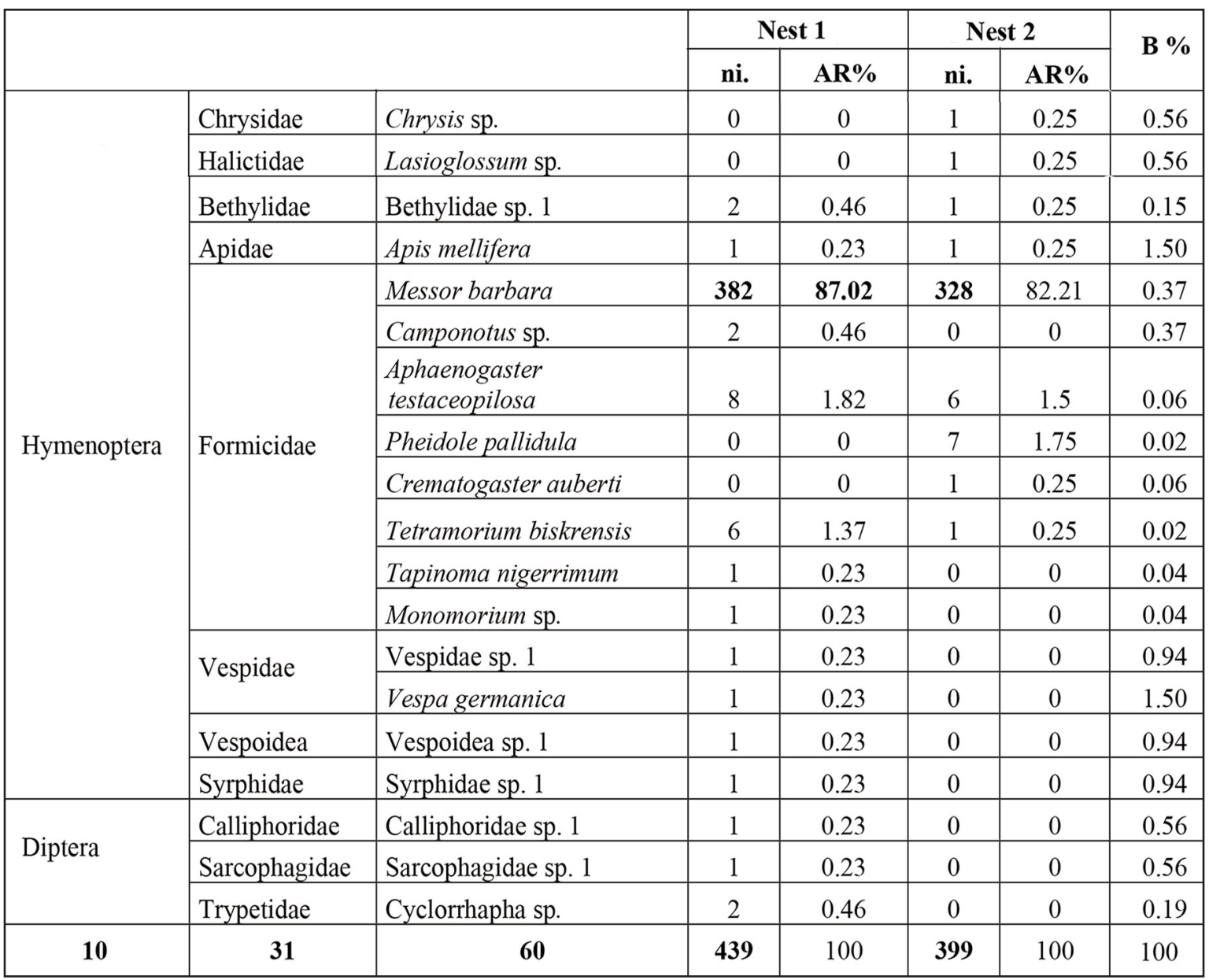

Table 1/2. Relative abundances of prey species inventoried at the entrance to the nest of Cataglyphis bicolor.

note that the $6 \mathrm{~mm}$ size species are the most consumed at $19.2 \%$. In the Reghaïa marsh, the $24 \mathrm{~mm}$ classes $(\mathrm{AR} \%=2.2 \%$, nest 1$)$ corresponding to Gryllidae sp. indet. and $30 \mathrm{~mm}(\mathrm{AR} \%=2.7 \%$, Nest 2) corresponding to Aiolopus strepens are poorly represented. At the Guayaza station near Djelfa, Guerzou (2009) reports that the $120 \mathrm{~mm}$ class corresponding to Lacertidae sp. indet. $(\mathrm{AR} \%=0.45 \%)$ is also poorly reported. Similarly, Ziada (2006) points out that the class of $100 \mathrm{~mm}$. corresponding to Chalcides ocellatus ( $\mathrm{AR} \%=0.06 \%$ ) is poorly reported.

\section{CONCLUSIONS}

The study of $C$. bicolor diet by the analysis of two nests in the natural reserve of the lake of
Reghaïa allowed us to find a total wealth of 60 species. Relative abundance shows that Messor barbara is the most abundant species in this ant's diet for both nests with $87 \%$ in Nest 1 and $82.2 \%$ in Nest 2.

In terms of biomass, a species of Ophonus sp. (B. $\%=9.36 \%)$ is prevalent. Yet, in terms of relative abundance, the latter species is poorly noted in the diet of this ant. In contrast, the species Messor barbarue, which dominates the other species in terms of relative abundance, represents only a very small part of the biomass ingested $(0.37 \%)$.

The most abundant size class is the $5 \mathrm{~mm}$, represented by Sinoxylon sp. and Ophthalmicus sp. for Nest 1. For Nest 2, the most represented size class is the $8 \mathrm{~mm}(18.9 \%)$. The size class of $8 \mathrm{~mm}$ corresponds to Cassida ferruginea, Carpocoris sp. and Otiorrhynchus sp. 


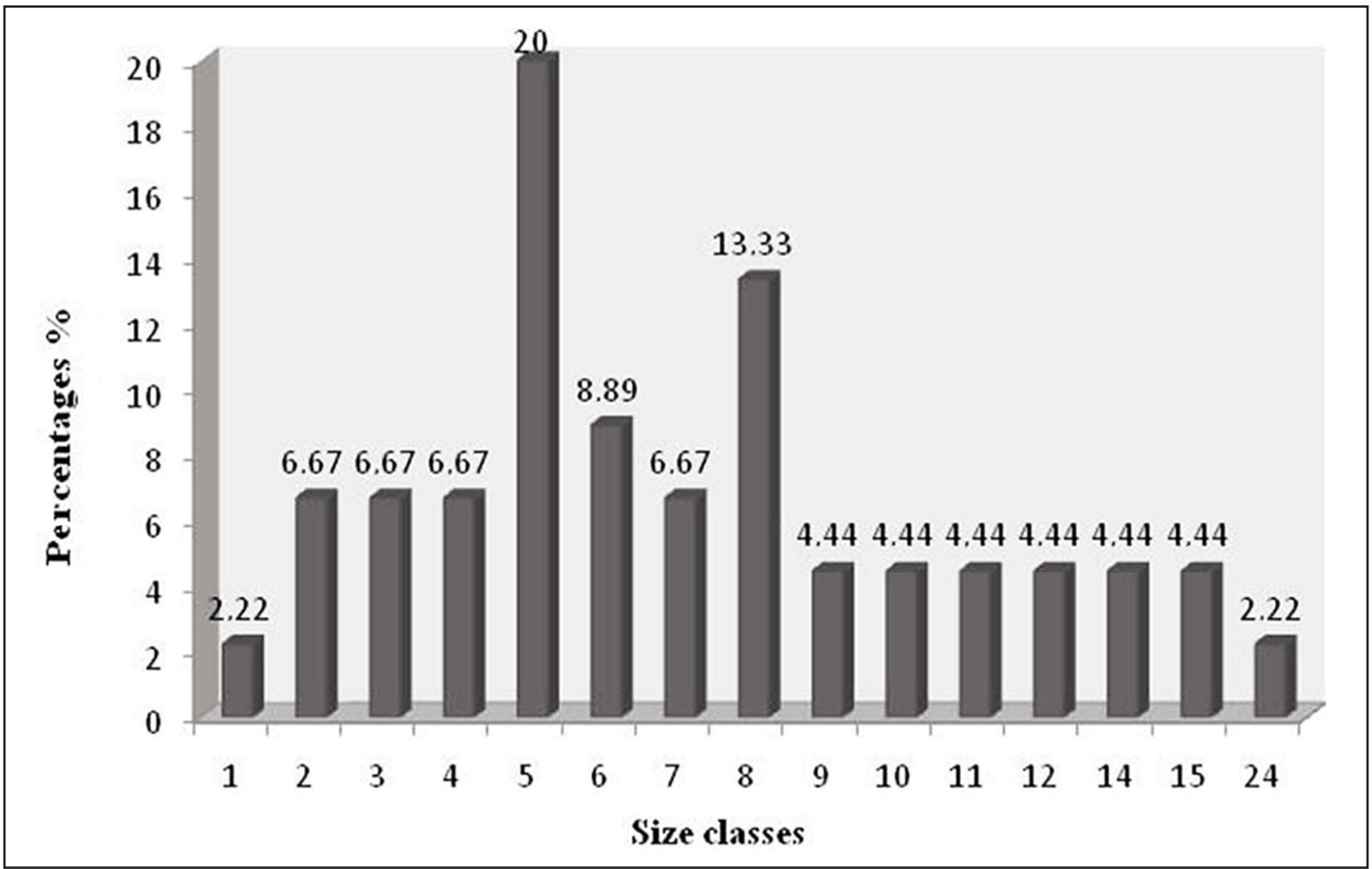

Figure 2. Size classes rate found in the Cataglyphis bicolor trophic menu near Reghaïa swamp in Nest 1.

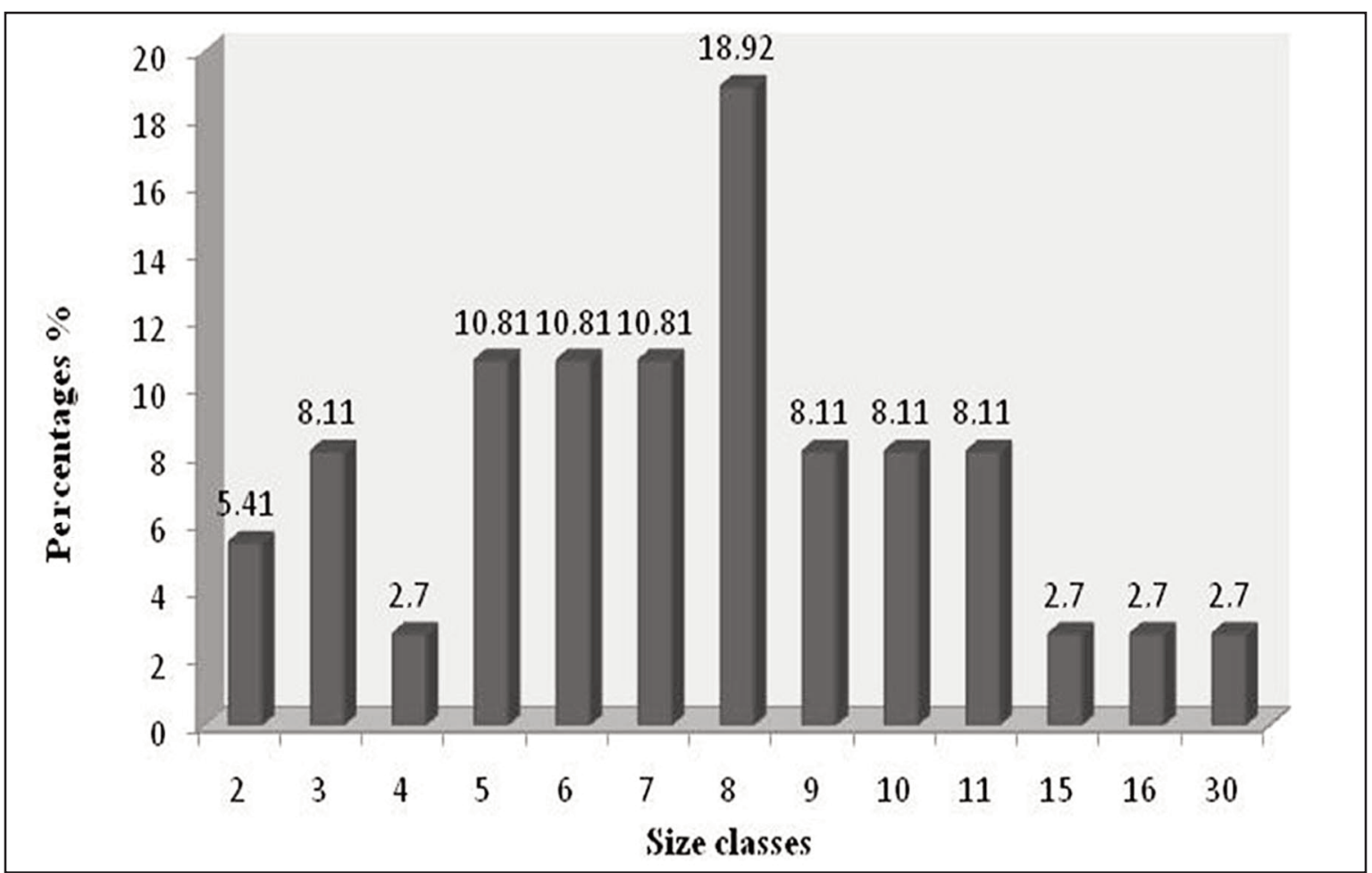

Figure 3. Size classes rates found in the trophic menu of Cataglyphis bicolor near Reghaïa swamp in Nest 2. 


\section{REFERENCES}

Baouane M., 2002. Bioécologie des oiseaux et relations trophiques entre quelques espèces animales des abords du marais de Réghaïa. Mémoire Ingénieur, Agronomic National Institute, El Harrach, 160 pp.

Barech G., 1999. Régime alimentaire des Formicidae en milieu agricole suburbain près d'El Harrach. Mémoire Ingénieur, Agronomic National Institute, El Harrach, $251 \mathrm{pp}$.

Bernard F., 1948. Le polymorphisme social et son déterminisme chez les fourmis. Ed. Station Zoologie University, Alger, 140 pp.

Bernard F., 1951. Super famille des Formicoidea, pp. 997 - 1104 pp. in Grassé P.P., Traité de Zoologie - Insectes supérieurs et Hémiptéroïdes. Ed. Masson \& Cie, Paris, vol. 10, Fasc. 2, 975-1948.

Bernard F., 1968. Les fourmis (Hymenoptera, Formicidae). Paris, Masson \& Cie, 411 pp.

Bigot L. \& Bodot P., 1973. Contribution à l'étude biocoénotique de la garrigue à Quercus coccifera. Vie et milieu, 23: 229-249.

Blondel J., 1969. Méthodes de dénombrement des populations d'oiseaux. In: Lamotte M. \& Bourliere F., Problèmes d'écologie. L'échantillonnage des peuplements animaux des milieux terrestres. Ed. Masson et Cie, Paris, pp. 7-151.

Cagniant H., 1973. Le peuplement des fourmis des forêts Algériennes écologie, biocénotique, essai écologique. Toulouse. Thèse Doctorat en Sciences Naturelles, $464 \mathrm{pp}$.

Cagniant H. 1973. Les peuplements de fourmis des forêts algériennes. Ecologie, Biocénotique, Essai biologique. Thèse Doctorat, University Toulouse, 464 pp.

Cagniant H., 2009. Le Genre Cataglyphis Foerster, 1850 au Maroc (Hyménoptères, Formicidae). Orsis, 24: 41-71.

Dajoz R., 1971. Précis d'écologie. Ed. Dunod, Paris, 434 pp.

Délye G., 1957. Observations sur la fourmi saharienne Cataglyphis bombycina (Rog.). Insectes Sociaux, 4: 77-82.

Délye G., 1974. Observations sur le comportement de la fourmi Cataglyphis bicolor (Fabricius) lors d'une éclipse totale de soleil. Insectes sociaux, 2: 369-380.

Dietrich B. \& Wehner R., 2003. Sympatry and allopatry in two desert ant sister species: how do Cataglyphis bicolor and C. savignyi coexist? Oecologia, 136: 6372.

Djennoune D., Marniche F., Amroun M. \& Boulay R., 2018. Comparative diet of hedgehogs (Atelerix algirus) in two localities in Kabylia, Algeria. Turkish Journal of Zoology, 42: 207-217.

Filali A. \& Doumandji S., 2008. Aperçu sur le régime al- imentaire de la fourm prédatrice Cataglyphis bicolor (Fabr., 1793) (Hymenoptera, Formicidae) dans un milieu agricole à Azzaba (W. Skikda). 3ème Journées Nationales sur la Protection des Végétaux, 7-8 avril 2008, Department of Agricultural and Forest Zooloy, Agronomic National Institut, pp. 60.

Grassé P.P., 1951. Traité de zoologie, anatomie systématique, biologie. Masson \& Cie, Paris, 10: 997-1119.

Guerzou A., 2009. Bioécologie trophique de quelques espèces prédatrices dans la région de Guelt es Stel (Djelfa). Thèse Magister, Agronomic National Institute, El Harrach, 305 pp.

Heusser D. \& Wehner R., 2002. The visual centring response in desert ants, Cataglyphis bicolor. The Journal of Experimental Biology, 205: 585-590.

Hölldobler E. \& Wilson E.O., 1993. Voyage chez les fourmis. Paris, Ed. du Seuil, 253 pp.

Molinari K., 1989. Etude faunistique et comparaison entre trois stations dans le marais de Réghaïa. Mémoire Ingénieur, Agronomic National Institute, El Harrach, 171 pp.

Moulai R., Maouche A. \& Madouri K., 2006a. Ecologie trophique de la fourmi prédatrice Cataglyphis bicolor (Hymenoptera, Formicidae) en relation avec les disponibilités du milieu dans la région de Béjaia (Algérie). 6ème Conférence International francophone Entomology (C.I.F.E), 2-6 juillet 2006, Rabat, Maroc, pp.70.

Moulai R., Maouche A. \& Madouri K., 2006b. Données sur le régime alimentaire de Cataglyphis bicolor (Hymenoptera, Formicidae) dans la région de Béjaia (Algérie). L'Entomologiste, 62: 37-44.

Mutin L., 1977. La Mitidja, décolonisation et espace géographique. Ed. Office Public University, Alger, 607 pp.

Ouarab S., Khaldi-Barech G., Ziada M. \& Doumandji S., 2006. Prédation de la fourmi Cataglyphis bicolor (Hymenoptera, Formicidae) notamment aux abords du marais de Reghaïa (Alger). Conférence Internatinal Francophone Entomology (C.I.F.E.), 2-6 juillet 2006, Institut Scientifique de Rabat, pp. 68.

Ouarab S., Khaldi-Barech G., Ziada M. \& Doumandji S., 2010. Prédation de la fourmi Cataglyphis bicolor (Hymenoptera, Formicidae) aux abords du marais de Réghaïa. Actes de la Conférence Internatinal Francophone Entomololy 6, Travaux de l'Institut Scientifique de Rabat, Série zoologique, Rabat, 47: 163168.

Sekour M., 2002. Relations trophiques entre quelques espèces animales de la réserve naturelle de Mergueb (M'Sila). Mémoire Ingénieur, Agronomic National Institute, El Harrach, 155 pp.

Sekour M., Baziz B., Souttou K., Doumandji S. \& BenBouzid N., 2007. Régime alimentaire de Cataglyphis sp. (Hymenoptera, Formicidae) dans la réserve na- 
turelle de Mergueb (M'Sila). Journées Internationales. Zoologie, agriculture, forêts, 8-12 avril, Department of Agricultural and Forest Zooloy, Agronomic National Institut, El Harrach, pp. 217.

Talmat N., 2002. Bioécologie, régime alimentaire de quelques espèces animales et reproduction de Larus cachinnans dans la région de Tigzirt et Iflissen (Grande Kabylie). Mémoire Ingénieur, Agronomic National Institute, El Harrach, 138 pp.

Vivien M.L., 1973. Régime et comportement alimentaire de quelques poissons des récifs coralliens de Tuléar, Madagascar. La Terre et La Vie, 27: 551-577.
Ziada M., 2006. Régime alimentaire de la fourmi prédatrice Cataglyphis bicolor (Fabricius, 1793) (Hymenoptera, Formicidae) dans la région de Guelma. Mémoire Ingénieur, Agronomic National Institute, El Harrach, 136 pp.

Ziada M. \& Doumandji S., 2008. Etude de l'aspect sélectif chez la fourmi prédatrice Cataglyphis bicolor (Hymenoptera, Formicidae) dans la région de Guelma. 3ème Journées National sur la Protection des Végétaux, 7-8 avril 2008. Department of Agricultural and Forest Zoology, Agronomic National Institut, El Harrach, $62 \mathrm{pp}$. 